\title{
HOW MUCH HEAVIER IS A "HOE" FOR WOMEN? WAGE GENDER DISCRIMINATION IN THE BRAZILIAN AGRICULTURAL SECTOR
}

\author{
O QUANTO A "ENXADA" É MAIS PESADA PARA AS \\ MULHERES? DISCRIMINAÇÃO SALARIAL DE GÊNERO NO \\ SETOR AGRÍCOLA BRASILEIRO
}

\section{¿CUÁNTO LA “AZADA" ES MÁS PESADA PARA LAS MUJERES? LA DISCRIMINACIÓN DEL GÉNERO EN EL SECTOR AGRÍCOLA BRASILEÑO}

Kalu Soraia Schwaab

Doutoranda em Administração na Universidade Federal de Santa Maria - UFSM

kaluschwaab@gmail.com

\section{Vanessa Rabelo Dutra}

Doutoranda em Administração na Universidade Federal de Santa Maria - UFSM

vanessardg@gmail.com

\section{Paulo Fernando Marschner}

Mestrando em Administração na Universidade Federal de Santa Maria - UFSM

paulofernandomarschner@hotmail.com

\section{Paulo Sergio Ceretta}

Professor no Programa de Pós-Graduação em Administração na Universidade Federal de Santa Maria - UFSM

Doutor em Engenharia de Produção - UFSC

ceretta10@gmail.com
Contextus

ISSNe 2178-9258

Organização: Comitê Científico Interinstitucional Editor-Chefe: Diego de Queiroz Machado Avaliação: double blind review pelo SEER/OJS

Recebido em 18/12/2018

Aceito em 03/03/2019

Versão final em 20/03/2019

http://dx.doi.org/10.19094/contextus.v17i2.39969

\begin{abstract}
This paper aims at analyzing the existence of wage differentials by genders in the agricultural labor market in the Brazilian rural area, with the purpose of verifying if the differentials are due to differences in explained characteristics or discriminatory. Equations were estimated and the wage differential detailed decomposition with microdata from the PNAD 2015 with the Heckman's correction. The method used was the decomposition of Oaxaca-Blinder. The main results show that the wage/hour of men is $157.62 \%$ higher than that of women, and the effect of discrimination is $108.38 \%$ this gap. The main conclusion indicates that the gender wage differential decreases with the formality of work and with the increase of hours worked by women. It is worth nothing that the results provide the visualization of gender discrimination in the rural labor market, adding contributions to the empirical studies on wage differentials.
\end{abstract}

Keywords: wage gap; gender; agricultural; rural; detailed decomposition.

RESUMO

Este trabalho tem como objetivo analisar a existência de diferenciais salariais por gênero no mercado de trabalho agrícola na zona rural brasileira, verificando se os diferenciais são oriundos de diferenças explicadas ou discriminatórias. Equações de rendimento e a decomposição detalhada do diferencial de salários por meio dos microdados da PNAD 2015, foram estimadas com a correção de Heckman. O método utilizado foi a decomposição 
de Oaxaca-Blinder. Os principais resultados mostram que o salário/hora dos homens é 157,62\% maior que o das mulheres e o efeito da discriminação corresponde a 108,38\% desse hiato. A principal conclusão indica que o diferencial salarial por gênero diminui com a formalidade do trabalho e com o aumento das horas trabalhadas pelas mulheres. Vale ressaltar que os resultados proporcionam a visualização da discriminação de gênero no mercado de trabalho rural, agregando contribuições aos estudos empíricos sobre os diferenciais salariais no setor agrícola.

Palavras-chave: diferencial salarial; gênero; agrícola; rural; decomposição detalhada.

\section{RESUMEN}

Este trabajo tiene como objetivo analizar la existencia de diferencias salariales por género en el mercado de trabajo agrícola en la zona rural brasileña, verificando si los diferenciales provienen de diferencias explicadas o discriminatorias. Las ecuaciones de rendimiento y la descomposición detallada del diferencial de salarios con los microdatos de la PNAD 2015 fueron estimadas con la corrección de Heckman. El método utilizado fue la descomposición Oaxaca-Blinder. Los principales resultados muestran que el salario/hora de los hombres es $157,62 \%$ mayor que el de las mujeres, y el efecto de la discriminación es 108,38\% de ese hiato. La principal conclusión indica que el diferencial salarial por género disminuye con la formalidad del trabajo y con el aumento de las horas trabajadas por las mujeres. Cabe resaltar que los resultados proporcionan la visualización de la discriminación de género en el mercado de trabajo rural, agregando contribuciones a los estudios empíricos sobre los diferenciales de salarios.

Palabras clave: diferencial salarial; género; agrícola; rural; descomposición detallada.

\section{INTRODUCTION}

The rural labor market has recently gained worldwide interest. Due to issues linked to agriculture, as well as to continued population growth and increasing land scarcity, the rural labor market is becoming increasingly important (HEADEY; JAYNE, 2014; HOLDEN; OTSUKA, 2014; NOLTE; OSTERMEIER, 2017). According to the World Bank (2016), almost half the world's population lives in rural areas. Although in Brazil most of the population living in urban areas, 76\% (WORLD BANK, 2016), it is in the rural area that the initial scenario of Brazilian agribusiness occurs. The agribusiness in Brazil accounts for $21.6 \%$ of the Brazilian GDP (CEPEA, 2017). Cepea (2018) indicates that the average wage paid to the agribusiness grew more than the average Brazilian economy in the period between 2012 and 2018. The average growth in the salaries of people employed in agribusiness was $10 \%$, while for Brazil it was $6.36 \%$. However, even so, wages in agribusiness are significantly lower than the national average.

Brazil has presented great inequality of income over time, which has led to many investigations and wide discussion (CIRINO; LIMA, 2012; ASSIS; ALVES, 2014; GUIMARAES; SILVA, 2016; UNDP, 2016). This issue requires caution because of its breadth since it involves issues from a variety of spheres, such as public policies for income distribution, economic development, justice and social equality (UNDP, 2016). Discrimination issues in relation to gender have raised relevant questions, whether in relation to the wage gap, the projection of the professional career, in the political arena, or around the role of women in 
modern society and their devaluation as a workforce. Some researchers have analyzed the issue of gender wage discrimination, covering all Brazilian territory, specific regions, and states, some even verifying differences between urban and rural areas (COELHO; CORSEUIL, 2002; CIRINO; LIMA, 2012). However, studies that analyze gender wage inequalities within the agricultural sector, and specifically in the Brazilian countryside, are still scarce.

Studies in several countries have analyzed income differentials among rural and urban populations, such as the United States (EWING; LEVERNIER, 2000), Uruguay (BERGOLO; CARBAJAL, 2010), Mexico (HAISKEN-DENEW; MICHAELSEN, 2011), India (AGRAWAL, 2013), and Brazil (NEY; HOFFMANN, 2009). These studies have identified that the main factors that contribute to income inequality among rural and urban workers are due to a significant portion of the human capital gap, highlighting the issue of schooling. Access to the educational system in rural areas is much more complicated by different situations such as the early entry of individuals into the labor market, the distance from rural properties to schools and the limitation of transportation. With this, poor rural families tend to have their income influenced due to low qualification (NEY; HOFFMANN, 2009). In addition, a study carried out in more than 150 countries shows that the average years of schooling of agricultural workers is lower than that of non-agricultural workers (GOLLIN; LAGAKOS; WAUGH, 2014). This study classified Brazil in the group with the largest gap between the two sectors (agricultural and non-agricultural).

Studies specifically on the agricultural sector specially in the countries in development indicate disadvantages in the labor market for women (AGUILAR et al., 2015; BIGLER et al., 2017; MAHAJAN; RAMASWAMI, 2017). The Instituto Brasileiro de Geografia e Estatística (IBGE) released indicators from Brazil which show that, in 2016, women received, on average, $23 \%$ less than men and $60.9 \%$ of management positions belonged to men (IBGE, 2018). In relation to time, women spend $42 \%$ more hours per week than men in people care and chores. Therefore, due to these attributions, they are formally occupied part-time, while the men are integrally (IBGE, 2018).

This work emerges by considering the peculiarities of the population in the rural agricultural sector, lower wages when compared to the urban area, the rural labor market, recently gained worldwide interest, difficult access to higher educational levels and supported by national gender statistics. The motivations for this research raised questions: how is the wage issue in the agricultural sector in the Brazilian countryside? How is the remuneration of the 
feminine gender? Are wage differentials arising from differences in human capital or discriminatory?

This paper aims at analyzing the existence of wage differentials between the genders in the agricultural labor market in the Brazilian rural area. With the purpose of verifying if the differentials are just or unjust, that is, whether they are due to differences in human capital or discriminatory. The secondary aim is to verify if there are wage differences in the different rural regions of Brazil. In this sense, analyzing the Brazilian rural agricultural population becomes relevant since it resumes this discussion around the discrimination in relation to the wage difference within a delimitation of a specific sector, which the role of the woman is important. In addition, this study differs from the others, because besides analyzing a specific sector, it makes use of the detailed decomposition of Oaxaca-Blinder, not yet used in the Brazilian rural context.

\section{PREVIOUS STUDIES}

There are many empirical studies addressing income and discrimination differentials in developed countries (EWING; LEVERNIER, 2000; ARULAMPALAM; BOOTH; BRYAN, 2007; TIVENTI, 2013) and in developing countries (NEY; HOFFMANN, 2009; BERGOLO; CARBAJAL，2010; HAISKEN-DENEW; MICHAELSEN，2011; AGRAWAL，2013; AGUILAR et al., 2015; BIGLER et al., 2017; MAHAJAN; RAMASWAMI, 2017).

In Brazil, some studies on the labor market examine wage differentials derived from discrimination. Most of the studies on wage differentials in the Brazilian labor market are based on data from surveys conducted by IBGE, using the National Household Sample Survey (PNAD). However, few studies consider in their analysis the incorporation of the PNAD sample plan. By ignoring the sampling plan, these surveys no longer cover all aspects that define a 'complex sampling plan' - stratification of sampling units, conglomeration, unequal selection probabilities in one or more stages and adjustments of sample weights for calibration with known population totals - and the studies assume that the sample design was a simple random sampling with replacement, obtaining in this way incorrect and skewed analyzes (SILVA; PESSOA; LILA, 2002). 
Skinner, Holt and Smith (1989) propose the extended concept of the Sample Plane Effect (misspecification effect), which allows to evaluate the impact of ignoring the structuring of population data or the sampling plan on estimating the variance of an estimator. The studies of Pessoa and Silva (1998) and Carvalho, Neri and Silva (2006) confirmed the impacts of disregarding the sample plan in analytical estimates, which could compromise the quality of the results.

There are studies in Brazil to verify gender payment differentials using the OaxacaBlinder decomposition methodology, considering sample plan and Heckman's correction, however, studies with this methodological rigor are infrequent in the agricultural sector and rural area. Some studies with adequate statistical modeling procedures in surveys by complex sampling such as the analysis of the tourism sector (GUIMARAES; SILVA, 2016), the migratory condition (ASSIS; ALVES, 2014), and the differential of salaries in metropolitan regions (CIRINO; LIMA, 2012).

Guimaraes and Silva (2016) have shown that there is gender discrimination regarding wages in the Brazilian tourism sector and that women are less valued than men even when they have similar characteristics. Assis and Alves (2014) verified whether the wage gap between sex and migrants is due to occupational segregation or possible signs of discrimination. This study found evidence that a large part of these wage differentials results from the existence of discrimination in the labor market.

In an approach to wage differentials by region, Cirino and Lima (2012) quantified the difference in hourly earnings between the metropolitan areas of Belo Horizonte and Salvador. Income in the metropolitan area of Belo Horizonte is, on average, higher than in Salvador, because of the greater concentration and economic agglomeration of the first region (CIRINO; LIMA, 2012).

Regarding the analysis of income inequalities in rural areas, the studies by Hoffmann (1993), Correa and Figueiredo (2006), Cunha (2008), among others, stand out. However, it is important to note that these studies considered only the sample expansion factor (weight), disregarding the entire sample plan in it analyzes, ignoring, for example, stratification and conglomeration information. 
RESEARCH HYPOTHESES

As in other sectors of the economy, the wages of rural agricultural workers depend on their individual skills, knowledge, and experience, as explained by The Human Capital Theory (BECKER, 1964; SCHULTZ, 1967; MINCER, 1974). However, disparities in the treatment of production profiles and inputs, such as deferrals by race or gender, can be explained by Discrimination Theory (BECKER, 1957). Just as wage differentials between regions can be explained by Segmentation Theory (DORINGER; PIORE, 1971; VIETORISZ; HARRISON, 1973). Therefore, the Human Capital Theory (TCH), Discrimination Theory (TD) and Segmentation Theory (TS), provide the theoretical framework of this research.

Human capital is defined as "productive wealth embodied in work, skills, and knowledge" (OECD, 2001) and refers to any stock of knowledge and acquired characteristics of a person, which contributes to their productivity (GARIBALDI, 2006). At the heart of TCH's approach is that such skills and knowledge can be acquired through education and training. This theory suggests that education and experience are important indicators of a worker's productivity.

For Becker (1964), TCH considers the process of acquisition of education as an investment based on the maximization of individual utility, while in Schultz's (1967) view, individuals investing in education extend their power of choice because of an increasingly restrictive and competitive labor market, people who are better prepared and educated will have more career choices. In this sense, Mincer (1974) states that the differences in income received by workers are explained by the different levels of investment in human capital. Thus, individuals employ time in the acquisition of knowledge with the expectation of receiving higher incomes in the future. According to TCH assumptions, the first and second hypotheses emerge (BECKER, 1964; SCHULTZ, 1967; MINCER, 1974).

H1: The wage/hour in the agricultural labor market in rural areas increases with schooling and with experience for both men and women.

H2: The wage/hour in the agricultural labor market in rural areas is affected by the existence of wage differentials due to the level of education between men and women.

Discrimination, in economics, can be defined as a differential treatment to groups with similar characteristics, based on criteria that do not matter to developed activity (BECKER, 
1957). Studies on discrimination in the labor market come from the seminal study of Becker (1957).

As in many sectors, there is evidence of horizontal and vertical segregation in relation to gender issues in the Brazilian agricultural sector. Indicators regarding the horizontal segregation of the labor market, women are concentrated in activities of people care and domestic tasks, reflecting the restriction of women to a small number of professions. The vertical segregation of the labor market refers to the concentration of women in the lower levels of the occupational hierarchy, with less than $40 \%$ of managerial positions belonging to women (IBGE, 2018). Based on TD (BECKER, 1957; PHELPS, 1972; ARROW, 1973), the third hypothesis of the study arises.

H3: Part of the wage differentials between men and women in the agricultural sector in rural areas derives from gender discrimination.

The wage differentials can also be traced to the segmentation effect of different regional characteristics, which in case of Brazil, due to the territorial dimension, show different levels of development (IBGE, 2017). In more developed regions, wages tend to be higher because of the created externalities, so workers with equal productive potential are pay differently (DOERINGER; PIORE, 1971; VIETORISZ; HARRISON, 1973, COELHO; CORSEUIL, 2002).

Brazil is marked by regional differences, both economic and social. The Southeast and South of the country stand out for presenting better economic and social indicators in relation to the rest of Brazil (IBGE, 2017). As for the agribusiness sector, the Midwest region presents an intense growth in the capital/labor ratio, with high levels of productivity and very high levels of capital intensity, showing the most developed and modernized rural area among the five Brazilian regions (CORREA; FIGUEIREDO, 2006). On the other hand, although its economy is large due to agricultural production, the Northeast presents low levels of modernization in the sector, exposing low social indicators compared to the national average and faces serious macro-structural problems (CORREA; FIGUEIREDO, 2006; IBGE, 2017). It is against this background (DOERINGER; PIORE, 1971; VIETORISZ; HARRISON, 1973) that the fourth hypothesis arises.

H4: The wage/hour of the agricultural sector in the rural area is different according to the region of Brazil. 


\section{METHODOLOGY}

The microdata of the PNAD, carried out in 2015 by IBGE, were used in this study. The PNAD database covers household residents and contains information on socioeconomic characteristics, especially in relation to employment and income of Brazilian workers. It provides detailed information on urban and rural areas, as well as information on formal and informal employment.

The PNAD incorporates a random sample of households obtained in three stages: i) primary units denominated municipalities; ii) secondary units, i.e. census tracts and; iii) tertiary units, also known as domiciles (private households and collective households). The database, therefore, contains a complex sampling plan insofar as it covers stratification, conglomeration, unequal selection probabilities, and sample weighting adjustments for the projection of population totals. In this study, all the estimates made considered the characteristics of the PNAD sample plan.

Based on the objective of the research, only those people living in the Brazilian countryside, linked to the agricultural activity, were selected, who declared that they were working in the reference week, with a positive income and aged between 14 and 65 years. The criteria adopted for age selection involves concepts of potentially active population, being adopted the minimum age of 14 years as it is allowed by law for work in Brazil (BRASIL, 2000). In this way, the sample comprises 13,790 people. It is important to highlight that the sample analyzed corresponds to a population of 8,292,922 people, which could be projected by the expansion factors or weights corresponding to each individual of the sample.

The variables used in the research are presented in Table 1. The natural logarithm of the wage/hour as the dependent variable is used to estimate the wage equation. The independent variables used are education, experience, geographic regions, formal work, hours of work, unionization and color or race. Education was measured in years of study. For the proxy of experience, the total number of years of study plus six (literacy) is subtracted from the age. In addition, the experience squared is used to capture the concave effect over time (MINCER, 1974). To evaluate the geographical regions, regional dummies are used to capture the effects of regional segmentation on wages.

Dummies variables are adopted to detect job characteristics. Regarding the concepts of formality and informality of work, there are different definitions that can lead to substantially 
different results, which makes the comparison between surveys more difficult. A typical classification in the Brazilian literature considers those who do not have a formal contract as informal workers (FERNANDES, 1996). However, the concept suggested by Telles (1992), and Kassouf (1998) classify those workers who do not contribute to social security as informal. In this research, it is adopted as a formal worker the one that contributes to social security. This choice is because many workers without a formal contract, such as the self-employed (lawyers, psychologists, engineers, and businessmen), would be classified as informal.

Table 1 - Description of the variables and expected effects on the wage estimation equation

\begin{tabular}{l|l|c}
\hline Variable & \multicolumn{1}{|c}{ Description of variable } & Wage \\
\hline LnWageHour & LnWageHour $=\ln \left[\frac{\text { V4718 }}{4 \text { HoursWeek }}\right]^{*}$ & Dependence \\
\hline D_Midwest & 1 if Midwest and 0 otherwise. & $+/-$ \\
\hline D_North & 1 if North and 0 otherwise. & $+/-$ \\
\hline D_Northeast & 1 if Northeast and 0 otherwise. & $+/-$ \\
\hline D_Southeast & 1 if Southeast and otherwise. & $+/-$ \\
\hline D_South & 1 if South and otherwise. & $+/-$ \\
\hline Study & Years of study & + \\
\hline Experience & Experience $=$ Age $-($ Study +6$)$ & + \\
\hline Experience^2 & Experience ${ }^{2}=\left[\frac{(\text { Experience })^{2}}{100}\right]^{* *}$ & + \\
\hline D_Formal & 1 when contributes to social security, 0 otherwise. & + \\
\hline HoursWeek & Hours worked per week the main job. & + \\
\hline D_White & $\begin{array}{l}1 \text { when the person self-declared white, } 0 \text { non-white (black and } \\
\left.\text { brown }{ }^{* * *}\right) .\end{array}$ & + \\
\hline D_TradeUnion & 1 if a member of a union and 0 otherwise. & + \\
\hline Soued &
\end{tabular}
Source: developed by the authors.

Note: ${ }^{*}$ V4718 is the name of the variable in the PNAD referring to the monthly income of the main job; ${ }^{* *}$ The criteria of dividing by one hundred is adopted to avoid very small coefficients; ${ }^{* * *}$ The color/race nomenclatures agree with the PNAD, being that in this research they were excluded from the 'yellow' and 'indigenous' analyzes.

The variable that reports the weekly workload is used since this question is a fundamental factor in the differential of occupational insertion between men and women. Women who need to reconcile paid work with housework and household care, in many cases, end up working in low-paid occupations (IBGE, 2018). Also, regarding the characteristics of work, a dummy is used for union membership, seeking to verify the existence of impact on the income. The dummy D_White is used to capture racial discrimination in the agrarian rural labor context.

As for the econometric model, to identify wage differentials by gender and to verify the existence of discrimination in the agricultural sector of the Brazilian rural environment, the method requires the estimation of income equations for these workers (female and male). The 
equations of income are based on the precepts of Mincer (1974), and in this study will be expanded through other variables, according to equation (1):

$$
\ln \left[w_{i}(e, x, y)\right]=\alpha+\beta_{1} e_{i}+\beta_{2} x_{i}+\beta_{3} x_{i}^{2}+\beta_{4} y_{i}+\mu
$$

In (1) $\ln \left[w_{i}(e, x, y)\right]$, is the natural logarithm of the hourly wage $w$ of individual $i$ in the agricultural sector living in the rural area; for the school level and, measured in years of study; and with experience $x ; y$ is the set of vectors to be estimated. $\alpha$ is a constant, $\beta_{1}, \beta_{2}, \beta_{3}$ and $\beta_{4}$ are parameter vectors associated to the vectors of the explanatory variables $e$, $x$ and described in Table $1,(i=1,2, \ldots, n)$ besides the stochastic error term, $\mu$, which contains unobservable characteristics.

In this study, it was included only the individuals with positive income, and thus, the unemployed and inactive were excluded. To correct problems arising from the non-random selection of the sample, it was applied the Tobit II model, developed by Heckman (1979). The Heckman procedure is widely used in the literature for correction of sample selection bias (CIRINO; LIMA, 2012; AGRAWAL, 2014; ASSIS; ALVES, 2014; GUIMARAES; SILVA, 2016).

The Heckman correction method estimates two equations. The first estimated equation is the one of selection, determining the probability of the person participating in the labor market. This is estimated by the Probit model. In the estimation of this equation it was obtained the lambda coefficient $(\lambda)$, also called the "Mills inverse ratio". The lambda coefficient is incorporated in the second equation, which is the income equation, thus correcting the selection bias. The selectivity term added to the income mincer equation $(\lambda)$ measures the effect of sample selection due to lack of observations on non-participant income (DOLTON; MAKEPEACE, 1986).

Due to the characteristics of the PNAD complex sample, the economic literature recommends the use of the Pseudo-Likelihood Method (BLINDER, 1983; SKINNER et al.,1989). It should be noted that with $w$ expressed in logarithmic form, the estimated marginal effect corresponds to a percentage change in real income per hour of work - exponential coefficient - [exponential (marginal effect) - 1] 100. 
After correcting the selection bias and estimating the income equations, it was adopted the threefold Oaxaca-Blinder (1973) decomposition, according to Hlavac (2018) to verify if the female workers in the rural sector receive the same remuneration as those of men. In the studies that address wage differentials, the Blinder-Oaxaca (1973) decomposition is the widely used methodology (CIRINO; LIMA, 2012; AGRAWAL, 2014; ASSIS; ALVES, 2014; GUIMARAES; SILVA, 2016). Through this decomposition, one can investigate whether income inequalities arise from discrimination or explainable factors, such as productive characteristics considered by TCH.

For the decomposition, Mincerian wage equations are estimated for two groups, according to equation (1). Group M (male gender, advantage group) and group F (female gender, disadvantaged group). From which the wage gap is verified, thus obtaining the wage differences estimated by the wage equations, denoted by the equation (2).

$$
D=E\left(\ln \left[w_{M}\right]\right)-E\left(\ln \left[w_{F}\right]\right)(2)
$$

Subsequently, the contribution of the differences in the regressor means (indicating the productive characteristics of the workers and other aspects associated with their positions in the labor market), the differences in the coefficients $\beta_{i}$ (their returns in terms of income of such attributes) and the interaction between these two aspects for D (CIRINO; LIMA, 2012; HLAVAC, 2018), through the following equation (3):

$$
D\left[E\left(x_{M}\right)-E\left(x_{F}\right)\right]^{\prime} \beta_{M}+E\left(x_{M}\right)^{\prime}\left(\beta_{M}-\beta_{F}\right)+\left[E\left(x_{M}\right)-E\left(x_{F}\right)\right]^{\prime}\left(\beta_{M}-\beta_{F}\right)
$$

In equation (3), called 'threefold' or 'triple' decomposition, the total differential between workers in the rural agricultural sector (by gender) is divided into three components: characteristic effect; unexplained or discrimination effect; and, interaction effect.

The term $\left[E\left(x_{M}\right)-E\left(x_{F}\right)\right]^{\prime} \beta_{M}$ represents the characteristic effect, which indicates the differences in income due to means of differentiation by the productive personal attributes of the workers and other aspects related to the insertion in the market of each group. The first part reflects the average increase in women's earnings if women had the same characteristics as men. The term $E\left(x_{M}\right)^{\prime}\left(\beta_{M}-\beta_{F}\right)$ represents the inexplicable component, or discrimination effect, 
that quantifies the change in wages of women when applying male coefficients to their characteristics, this effect includes differences in the constant of the model. The term $\left[E\left(x_{M}\right)-E\left(x_{F}\right)\right]^{\prime}\left(\beta_{M}-\beta_{F}\right)$ measures the simultaneous interaction between the differences in the explained characteristics and the differences in the coefficients between both genders.

\section{EMPIRICAL RESULTS AND DISCUSSION}

Based on the descriptive statistics in Table 2, it can be verified that the sample is composed of 9,536 men, representing a population of 5,686,970 male agricultural workers in rural Brazil. The sample of women is 4,254, representing a sample expansion of 2,605,952 women agricultural workers in the Brazilian rural zone. Of the total men, $45.57 \%$ are in the Northeast. The same is true for women, of which $45.95 \%$ are concentrated in the Brazilian Northeast.

It is noteworthy that women have a mean educational level of 6.02 years, while men, of 5.71 years, however, women receive lower wages/hour than men (women: R\$ 1.37 and men: $\mathrm{R} \$ 4.80)$. Regarding the number of hours worked per week, women have the lowest weekly average (20.93 hours/week). This evidence is in line with the report produced by IBGE, since women are more involved in household activities or caring for people, which determines a partial weekly workload. As for proxy for the formality of work, formal workers are a minority in both genders in Brazil (women: $14.81 \%$ and men: $24.84 \%$ of the sample). This information is in line with the rural reality of other countries, as highlighted by Bliger et al. (2017) in a study on Rwanda, which demonstrates that women are self-employed farmers and informal workers.

Still, in relation to Table 2, it is possible to identify the gender differences in the Brazilian rural context regarding color or race and participation in trade unions in which men and women are inserted.

Table 2 - Descriptive statistics (means and sample proportions) of variables associated with socioeconomic characteristics of rural agricultural workers in Brazil, 2015

\begin{tabular}{l|r|r}
\hline Variables & \multicolumn{1}{|c}{ Female } & \multicolumn{1}{c}{ Male } \\
\hline Agricultural workers & 4,254 & 9,536 \\
\hline Projection - sample expansion & $2,605,952$ & $5,686,970$ \\
\hline Study (years) & 6.02 & 5.71 \\
\hline Wage/hour (R\$) & 1.37 & 4.80
\end{tabular}

(TO BE CONTINUED) 
(CONTINUATION)

Experience (years)

\begin{tabular}{l|r|r} 
Experience (years) & 30.13 & 27.82 \\
\hline Hours worked per week (hours) & 20.93 & 37.40 \\
\hline North & $12.05 \%$ & $14.32 \%$ \\
\hline Northeast & $45.95 \%$ & $45.57 \%$ \\
\hline Southeast & $19.48 \%$ & $19.71 \%$ \\
\hline South & $17.69 \%$ & $13.88 \%$ \\
\hline Midwest & $4.83 \%$ & $6.52 \%$ \\
\hline Formality & $14.81 \%$ & $24.84 \%$ \\
\hline White & $35.44 \%$ & $33.17 \%$ \\
\hline Trade Union & $37.66 \%$ & $24.85 \%$ \\
\hline
\end{tabular}

Source: developed by the authors based on data from PNAD/IBGE-2015.

Table 3 shows the marginal effect of income equations on the rural labor market by gender. Analyzing the results of the income equations, it is highlighted that, most of the variables were significant, at least at the $5 \%$ level.

Table 3 - Income estimation equations with Heckman correction, rural area of Brazil, 2015

\begin{tabular}{|c|c|c|c|c|c|c|}
\hline \multirow{2}{*}{$\begin{array}{l}\text { Gender } \\
\text { Variables }\end{array}$} & \multicolumn{3}{|c|}{ Female } & \multicolumn{3}{|c|}{ Male } \\
\hline & \multicolumn{2}{|c|}{ LnWageHour } & \multirow{2}{*}{$\begin{array}{l}\text { LnWageHour } \\
\text { (E.C.) } \\
-0.2286\end{array}$} & \multicolumn{2}{|c|}{ LnWageHour } & \multirow{2}{*}{$\begin{array}{c}\text { LnWageHour } \\
\text { (E.C.) } \\
-0.2981\end{array}$} \\
\hline D_North & -0.2595 & *** & & -0.3540 & **** & \\
\hline & $(-0.1026)$ & & & $(-0.0586)$ & & \\
\hline \multirow[t]{2}{*}{ D_Northeast } & -0.3756 & **** & -0.3131 & -0.7592 & **** & -0.5320 \\
\hline & $(-0.0880)$ & & & $(-0.0495)$ & & \\
\hline \multirow[t]{2}{*}{ D_Southeast } & -0.2686 & **** & -0.2356 & -0.2557 & ***** & -0.2256 \\
\hline & $(-0.0993)$ & & & $(-0.0499)$ & & \\
\hline \multirow[t]{2}{*}{ D_South } & -0.3392 & **** & -0.2877 & -0.3618 & $* * *$ & -0.3036 \\
\hline & $(-0.1045)$ & & & $(-0.0576)$ & & \\
\hline \multirow[t]{2}{*}{ D_Formal } & 0.6717 & $* * *$ & 0.9576 & 0.4989 & **** & 0.6469 \\
\hline & $(-0.0776)$ & & & $(-0.0332)$ & & \\
\hline \multirow[t]{2}{*}{ D_TradeUnion } & -0.1743 & **** & -0.1600 & -0.0772 & $* * *$ & -0.0743 \\
\hline & $(-0.0431)$ & & & $(-0.0275)$ & & \\
\hline \multirow[t]{2}{*}{ D_White } & -0.0942 & ** & -0.0899 & 0.0879 & **** & 0.0919 \\
\hline & $(-0.0409)$ & & & $(-0.0257)$ & & \\
\hline \multirow[t]{2}{*}{ Study } & 0.0248 & **** & 0.0251 & 0.0482 & $* * *$ & 0.0494 \\
\hline & $(-0.0066)$ & & & $(-0.0043)$ & & \\
\hline \multirow[t]{2}{*}{ Experience } & 0.0120 & $* * *$ & 0.0121 & 0.0521 & $* * *$ & 0.0535 \\
\hline & $(-0.0040)$ & & & $(-0.0029)$ & & \\
\hline \multirow[t]{2}{*}{ Experience $^{\wedge} 2$} & -0.0089 & & -0.0089 & -0.0665 & $* * *$ & -0.0643 \\
\hline & $(-0.0072)$ & & & $(-0.0049)$ & & \\
\hline \multirow[t]{2}{*}{ HoursWeek } & 0.0020 & & 0.0020 & -0.0059 & **** & -0.0059 \\
\hline & $(-0.0017)$ & & & $(-0.0013)$ & & \\
\hline \multirow[t]{2}{*}{ Constant } & 0.4142 & $* * *$ & & 0.7513 & $* * *$ & \\
\hline & $(-0,1237)$ & & & $(-0,0780)$ & & \\
\hline
\end{tabular}

(TO BE CONTINUED) 


\section{(CONTINUATION)}

\begin{tabular}{l|c|c} 
Rho & $-0.2939^{* * *}$ & $-0.3254^{* * *}$ \\
\hline Sigma & $(-0.0530)$ & $(-0.0565)$ \\
\hline & $-0.2217^{* * *}$ & $-0.2016^{* * *}$ \\
\hline $\mathrm{N}$ & $(-0.0326)$ & $(-0.0155)$ \\
\hline
\end{tabular}

Source: developed by the authors based on data from PNAD/IBGE-2015.

Note: standard error in parentheses; $* * * \mathrm{p}<0.01, * * \mathrm{p}<0.05, * \mathrm{p}<0.1 ;$ E.C. $=$ Exponential Coefficient.

Estimating the equations, the results for the Midwest region were omitted in the model, in this way it was possible to identify it as the region of reference. In the context of the Brazilian territorial dimension, the Midwest has an area of 1,606,399,509 $\mathrm{km}^{2}$, corresponding to $18.86 \%$ of the national territory, being the second largest region of the country in territorial extension (IBGE, 2017). The Midwest stands out for the development and agrarian modernization in terms of rural area, presenting high levels of productivity and very high levels of intensity of capital use (CORREA; FIGUEIREDO, 2006).

It is observed that the coefficients of all regions are significant for both genders and that all have negative coefficients, indicating that the income in the Midwest region for the rural agricultural sector is higher than in the other regions. Among the regions, the one with the greatest negative impact in the Northeast. Thus, comparing women residing in the Midwest with those living in the Northeast, they suffer a negative marginal effect in the income of $31.31 \%$, and men, in turn, have a higher penalty, in the income of $53.20 \%$. These differences may be due to factors associated with the regional development and agricultural modernization since the Midwest region presents the intensity of capital use and high levels of modernization (CORREA; FIGUEIREDO, 2006). On the other hand, the Northeast states, except the state of Alagoas, have low levels of modernization factors.

Regarding schooling, it is observed that the results are in accordance with the TCH, which indicates that the higher the educational level, the higher the income. The results indicate that an additional year of study reflects a wage gain of $4.94 \%$ for men and $2.51 \%$ for women. The experience variable has a positive and significant coefficient in both equations, according to the literature (BECKER, 1964; MINCER, 1974). Men receive 5.35\% more for a longer experience, while for women the exponential coefficient is only $1.21 \%$.

As for the proxy used for work formality, it was observed a marginal effect on positive income, with similar results in Guimaraes and Silva (2016). The impact for men is $64.69 \%$ and for women, $95.76 \%$ more on the wage/hour compared to informal workers. The issue of being 
affiliated with a trade union generates a negative effect on the income of both genders, contrary to the study of Guimaraes and Silva (2016).

Regarding color or race, it was identified, contrary to expectations, that white woman, in this sector, suffer a penalty on income in relation to non-whites. This effect is $8.99 \%$ less in income. This result differs from the results observed in other studies of different sectors of the economy (CIRINO; LIMA, 2012; ASSIS; ALVES, 2014; GUIMARAES; SILVA, 2016). For men, the opposite happens, those of color or white race have a marginally positive effect, being this of $9.19 \%$ more in income relative to non-whites. These findings are in agreement with the empirical studies mentioned.

The variable that captures the effect of hours worked per week showed a significant negative coefficient for men only. Therefore, the more hours men work, the lower the wages/hour. This result can be related to questions of type of work, level of knowledge and agricultural modernization (CORREA; FIGUEIREDO, 2006). Jobs at operational levels, for example, generally require more time to execute and are worse paid.

The results of Table 4 demonstrate the decomposition Oaxaca-Blinder of the wage differential by genders. It was observed that the wage/hour coefficient of men is 1.2236 and that of women is 0.2773 , so the coefficient of the gender wage differential is 0.9463 . When it was applied the exponential coefficient in the difference, it was observed that the wage/hour of men is $157.62 \%$ higher than that received by women.

Table 4 - Decomposition by gender of agricultural sector, rural Brazil, 2015

\begin{tabular}{l|c|c|c|c}
\hline \multicolumn{5}{|c}{ Differential by Gender } \\
\hline Gender & Coefficient & Standard Error & p-value & E.C. \\
\hline Male & 1.2236 & 0.0262 & 0.0000 & 2.3994 \\
\hline Female & 0.2773 & 0.0209 & 0.0000 & 0.3196 \\
\hline Difference & 0.9463 & 0.0256 & 0.0000 & 1.5762 \\
\hline
\end{tabular}

Differential Decomposition

\begin{tabular}{l|c|c|c|c|c}
\hline Composition & Coefficient & Standard Error & p-value & R.P. (\%) & E.C. \\
\hline Characteristic effect & 0.2208 & 0.0227 & 0.0000 & 23.3330 & 0.2471 \\
\hline Discrimination effect & 1.0255 & 0.0324 & 0.0000 & 108.3800 & 1.7888 \\
\hline Interaction effect & -0.3001 & 0.0336 & 0.0000 & -31.7139 & -0.2593 \\
\hline
\end{tabular}

Source: developed by the authors based on data from PNAD/IBGE-2015.

Note: R.P. $=$ Relative Participation; E.C. $=$ Exponential Coefficient.

By the decomposition of income gap by gender (0.9463), it can be observed that the characteristic effect $(0.2208)$ and the discrimination effect (1.0255) increase the wage gap between men and women because they present positive coefficients. The characteristic effect 
is statistically significant at $1 \%$ and contributes $23.33 \%$ to the income differential by genders. This result contradicts other studies (GUIMARAES; SILVA, 2016), which found a negative sign for this effect in the tourism sector. The positive sign of the characteristic effect explains part of the wage differences by genders in the Brazilian agricultural sector.

The discrimination effect quantifies the change in wages for women by applying the male coefficients to the variables analyzed for women. The discrimination effect is statistically significant at $1 \%$, representing $110.19 \%$ of the wage gap per hour. Thus, it can be inferred that a large part of the income differential by genders is due to discrimination. The result is that if the male coefficients were applied to the characteristics of the women, that is, if there were no discrimination, women would have a wage increase of $183.35 \%$. On the other hand, the interaction effect reduces the gender wage differential by $27.16 \%$. This means that the simultaneous effect of some variables of the characteristics and of the discrimination effect amortizes the wage differential.

Table 5 presents the detailed wage decomposition by gender. In the detailed analysis of the decomposition between the groups composed the characteristic effect is shown in Table 5 . Among the significant variables, the variable referring to the hours worked per week and the dummy that identifies the formality of the work were the ones that contributed the most, respectively (59.65\% and 36.19\%), to the positive effect of the characteristics. Thus, most of the gender pay gap is explained by men working more hours per week than women, as well as occupying formal job positions (see Table 2). According to the IBGE (2018), women are concentrated in part-time and informal jobs. These results indicate that the factors mentioned partially explain lower wages for rural women living in rural areas in 2015. Regarding this result, the importance of labor legislation and protection of women is highlighted. However, Bliger et al. (2017) affirm what policies and laws encourage women to be part of the paid labor market, but only women with formal employment benefit from legislation.

Observing the significant variables (Table 5), it can be noticed that the variables Study and Experience present a negative sign reducing the wage gap between genders. However, the marginal impacts are small in magnitude, being overlapping by the impacts of the other variables with a positive sign. Regarding the years of study, it is observed that this contributes $1.81 \%$ to reduce the salary gap explained, while the professional experience has the contribution of $8.69 \%$. 
Table 5 - Detailed wage decomposition by gender: Characteristics effect, rural area of Brazil, 2015

\begin{tabular}{|c|c|c|c|c|}
\hline \multirow{3}{*}{$\begin{array}{l}\text { Variables } \\
\text { D_North }\end{array}$} & \multicolumn{4}{|c|}{ Characteristics effect } \\
\hline & \multicolumn{2}{|c|}{ Coefficients } & \multirow{2}{*}{$\begin{array}{c}\text { P.R. (\%) } \\
-1.2228\end{array}$} & \multirow{2}{*}{$\begin{array}{c}\text { E. C. } \\
-0.0027\end{array}$} \\
\hline & -0.0027 & & & \\
\hline & $(-0.0020)$ & & & \\
\hline \multirow[t]{2}{*}{ D_Northeast } & 0.0029 & & 1.3134 & 0.0029 \\
\hline & $(-0.0023)$ & & & \\
\hline \multirow[t]{2}{*}{ D_Southeast } & -0.0010 & & -0.4529 & -0.0010 \\
\hline & $(-0.0018)$ & & & \\
\hline \multirow[t]{2}{*}{ D_South } & 0.0067 & $* *$ & 3.0344 & 0.0067 \\
\hline & $(-0.0033)$ & & & \\
\hline \multirow[t]{2}{*}{ D_Formal } & 0.0799 & $* * *$ & 36.1866 & 0.0832 \\
\hline & $(-0.0107)$ & & & \\
\hline \multirow[t]{2}{*}{ D_TradeUnion } & 0.0149 & $* * *$ & 6.7482 & 0.0150 \\
\hline & $(-0.0038)$ & & & \\
\hline \multirow[t]{2}{*}{ D_White } & 0.0005 & & 0.2264 & 0.0005 \\
\hline & $(-0.0005)$ & & & \\
\hline \multirow[t]{2}{*}{ Study } & -0.0040 & ** & -1.8116 & -0.0040 \\
\hline & $(-0.0016)$ & & & \\
\hline \multirow[t]{2}{*}{ Experience } & -0.0192 & $* * *$ & -8.6957 & -0.0190 \\
\hline & $(-0.0064)$ & & & \\
\hline \multirow[t]{2}{*}{ Experience $^{\wedge} 2$} & 0.0112 & *** & 5.0725 & 0.0113 \\
\hline & $(-0.0053)$ & & & \\
\hline \multirow[t]{2}{*}{ HoursWeek } & 0.1317 & **** & 59.6467 & 0.1408 \\
\hline & $(-0.0199)$ & & & \\
\hline \multirow[t]{2}{*}{ Total } & 0.2208 & $* * *$ & 100.0000 & 0.2471 \\
\hline & $(-0.0227)$ & & & \\
\hline
\end{tabular}

Source: developed by the authors based on data from PNAD/IBGE-2015.

Note: standard error in parentheses; $* * * \mathrm{p}<0.01, * * \mathrm{p}<0.05, * \mathrm{p}<0.1$; R.P. $=$ Relative Participation; E.C. $=$ Exponential Coefficient.

In the detailing of the decomposition of the unexplained effects, that is, of the discrimination effect is shown in Table 6. The variable Experience has a greater individual contribution to the discrimination effect (130.53\%). It demonstrates that if there were no gender discrimination, women would have an increase of $281.41 \%$ in wage/hour, related to the variable Experience. This result is obtained by applying the male coefficient to the female experience, which is possibly related to the highest average female work experience (see Table 2). Therefore, women are not being remunerated in the same way as men (see Table 3).

The study variable (Table 6), individually, presents the contribution of $19.00 \%$ in the discrimination effect. Thus, in the absence of wage discrimination, women would receive $21.52 \%$ more by the level of study. Therefore, the difference in levels of schooling between 
genders is partly responsible for receiving more wages per hour for men than for women, although women have a higher average level of schooling (see Table 2). The constant has a contribution in the composition of the differential by discrimination (74.02\%), which, individually, has a $113.66 \%$ higher income for men. This means that the decomposed differential starts from a high wage gap against women. This portion is generally attributed to discrimination, but it is important to mention that it also captures gender differences in variables not observed in the study.

Table 6 - Detailed wage decomposition by gender: Discrimination effect, rural area of Brazil, 2015

\begin{tabular}{|c|c|c|c|c|}
\hline \multirow{3}{*}{$\begin{array}{l}\text { Variables } \\
\text { D_North } \\
\end{array}$} & \multicolumn{4}{|c|}{ Discrimination effect } \\
\hline & \multicolumn{2}{|c|}{ Coefficients } & \multirow{2}{*}{$\begin{array}{c}\text { P.R. (\%) } \\
-3.0129\end{array}$} & \multirow{2}{*}{$\begin{array}{c}\text { E. C. } \\
-0.0304\end{array}$} \\
\hline & -0.0309 & $* * *$ & & \\
\hline & $(-0.0099)$ & & & \\
\hline \multirow[t]{2}{*}{ D_Northeast } & -0.2812 & *** & -27.4181 & -0.2451 \\
\hline & $(-0.0380)$ & & & \\
\hline \multirow[t]{2}{*}{ D_Southeast } & -0.0209 & & -2.0378 & -0.0207 \\
\hline & $(-0.0147)$ & & & \\
\hline \multirow[t]{2}{*}{ D_South } & -0.0306 & $* *$ & -2.9836 & -0.0301 \\
\hline & $(-0.0153)$ & & & \\
\hline \multirow[t]{2}{*}{ D_Formal } & -0.0250 & $* *$ & -2.4376 & -0.0247 \\
\hline & $(-0.0102)$ & & & \\
\hline \multirow[t]{2}{*}{ D_TradeUnion } & 0.0138 & & 1.3456 & 0.0139 \\
\hline & $(-0.0133)$ & & & \\
\hline \multirow{2}{*}{ D_White } & 0.0405 & $* * *$ & 3.9489 & 0.0413 \\
\hline & $(-0.0118)$ & & & \\
\hline \multirow[t]{2}{*}{ Study } & 0.1949 & $* * *$ & 19.0035 & 0.2152 \\
\hline & $(-0.0319)$ & & & \\
\hline \multirow[t]{2}{*}{ Experience } & 1.3387 & **** & 130.5285 & 2.8141 \\
\hline & $(-0.1137)$ & & & \\
\hline \multirow[t]{2}{*}{ Experience $^{\wedge} 2$} & -0.6541 & $* * *$ & -63.7773 & -0.4801 \\
\hline & $(-0.0713)$ & & & \\
\hline \multirow[t]{2}{*}{ HoursWeek } & -0.2789 & $* * *$ & -27.1938 & -0.2434 \\
\hline & $(-0.0369)$ & & & \\
\hline \multirow[t]{2}{*}{ Constant } & 0.7592 & **** & 74.0250 & 1.1366 \\
\hline & $(0.1042)$ & & & \\
\hline \multirow[t]{2}{*}{ Total } & 1.0256 & $* * *$ & 100.0000 & 1.7888 \\
\hline & $(-0.0362)$ & & & \\
\hline
\end{tabular}

Source: developed by the authors based on data from PNAD/IBGE-2015.

Note: standard error in parentheses; $* * * \mathrm{p}<0.01, * * \mathrm{p}<0.05, * \mathrm{p}<0.1$; R.P. $=$ Relative Participation; E.C. $=$ Exponential Coefficient. 
The interaction effect has a control function to verify the proportion of the effects of the variables that occur concomitantly. The detailing of the interaction differential between the two terms is shown in Table 7. The variable that captures the effect of hours worked per week is the one that has the greatest participation in the simultaneous effect of differences $(78.74 \%)$, reducing the wage gap by genders in $21.05 \%$. The experience variable contributes $36.98 \%$ in the composition of the interaction effect, reducing the wage gap by $10.51 \%$.

Table 7 - Detailed wage decomposition by gender: Interaction effect, rural area of Brazil, 2015

\begin{tabular}{|c|c|c|c|c|}
\hline \multirow{2}{*}{ Variables } & \multicolumn{4}{|c|}{ Interaction effect } \\
\hline & \multicolumn{2}{|c|}{ Coefficients } & \multirow{2}{*}{$\begin{array}{c}\text { P.R. (\%) } \\
2.3659 \\
\end{array}$} & \multirow{2}{*}{$\begin{array}{c}\text { E. C. } \\
-0.0071\end{array}$} \\
\hline D_North & -0.0071 & $* *$ & & \\
\hline & $(-0.0029)$ & & & \\
\hline \multirow{2}{*}{ D_Northeast } & 0.0121 & & -4.0320 & 0.0122 \\
\hline & $(-0.0082)$ & & & \\
\hline \multirow[t]{2}{*}{ D_Southeast } & -0.0007 & & 0.2333 & -0.0007 \\
\hline & $(-0.0014)$ & & & \\
\hline \multirow[t]{2}{*}{ D_South } & 0.0061 & $*$ & -2.0327 & 0.0061 \\
\hline & $(-0.0034)$ & & & \\
\hline \multirow[t]{2}{*}{ D_Formal } & -0.0202 & $* *$ & 6.7311 & -0.0200 \\
\hline & $(-0.0082)$ & & & \\
\hline \multirow[t]{2}{*}{ D_TradeUnion } & -0.0048 & & 1.5995 & -0.0048 \\
\hline & $(-0.0046)$ & & & \\
\hline \multirow[t]{2}{*}{ D_White } & -0.0021 & & 0.6998 & -0.0021 \\
\hline & $(-0.0013)$ & & & \\
\hline \multirow[t]{2}{*}{ Study } & -0.0082 & $* * *$ & 2.7324 & -0.0082 \\
\hline & $(-0.0029)$ & & & \\
\hline \multirow[t]{2}{*}{ Experience } & -0.1110 & $* * *$ & 36.9877 & -0.1051 \\
\hline & $(-0.0166)$ & & & \\
\hline \multirow[t]{2}{*}{ Experience $^{\wedge} 2$} & 0.0721 & $* * *$ & -24.0253 & 0.0748 \\
\hline & $(-0.0125)$ & & & \\
\hline \multirow[t]{2}{*}{ HoursWeek } & -0.2363 & **** & 78.7404 & -0.2105 \\
\hline & $(-0.0313)$ & & & \\
\hline Total & -0.3001 & $* * *$ & 100.0000 & -0.2593 \\
\hline
\end{tabular}

Source: developed by the authors based on data from PNAD/IBGE-2015.

Note: standard error in parentheses; $* * * \mathrm{p}<0.01, * * \mathrm{p}<0.05, * \mathrm{p}<0.1$; R.P. $=$ Relative Participation; E.C. $=$ Exponential Coefficient.

As for the discrimination effect of the wage differential, the variables related to schooling and experience are the ones that contribute most to the gender wage gap. When analyzing the income equation, it is observed that each additional year of study is remunerated differently, depending on the gender - female (2.51\%) and male (4.94\%). As well, increases in 
professional experience also show a difference in remuneration for men (5.35\%) and women (1.21\%). The combined analysis of the income equations (see Table 3) and the detailed wage decomposition (see Table 6) provide a better insight into the occurrence of wage discrimination by genders.

\section{CONCLUSION REMARKS}

This paper aims at analyzing the existence of wage differentials between the genders in the agricultural labor market in the Brazilian rural area with the purpose of verifying if the differentials are just or unjust, that is, whether they are due to differences in human capital or discriminatory. The secondary aim is to verify if there are wage differences in the different rural regions of Brazil. The study is based on $\mathrm{TCH}, \mathrm{TD}$, and TS, and consists of estimating wage equations for each gender (MINCER, 1974) with the correction of Heckman's selection bias by using the microdata of PNAD 2015. In order to distinguish the origin of wage differences, the method of Decomposition Oaxaca-Blinder (1973) is composed of three effects: the characteristic effect, discrimination effect, and interaction effect.

In the analysis of the decomposition of the gender wage differential, the main results showed that the wage/hour of men is $157.62 \%$ higher than women. The characteristic effect contributed $23.33 \%$ to increase the income differential by genders, and the discrimination effect has a greater participation in the gap composition, increasing it by $108.38 \%$. While the interaction effect between the two terms reduces the wage gap by genders, composing $-31.71 \%$ in the composition of the differential.

Regarding schooling and experience, it is observed that the results agree with the TCH, which indicates that the higher the educational level and the experience, the higher the income. Therefore, the results of study and experience variables confirm hypothesis 1 . However, the results show that an additional year of study reflects on a different gain in wages for men and women. The same is true when analyzing the experience since men receive more wages/hours in the agricultural labor market in the rural area by the time of experience compared with the effect of this variable for women.

Although the level of education produces an increase in the wage/hour for men and women, it is evident that this impact is different. This result is supported by the evidence derived 
from the discrimination effect on the wage differential, since the difference in the levels of schooling between the genders is partly responsible for receiving more wages per hour for men than for women, although women have held the higher average level of schooling. In this sense and based on this evidence is that hypothesis 2 is not rejected.

Considering the results of the wage decomposition of Oaxaca-Blinder (1973), the discrimination effect accounts for most of the wage differential by genders, and this effect alone accounts for a wage/hour $178.88 \%$ higher for men than for women. Evaluating this result, it can be inferred that part of the wage differentials between men and women in the agricultural sector in the rural area is based on gender discrimination, confirming the hypothesis 3 of the research.

The main differences in wages were found, the Northeast region of Brazil is the one with the lowest wage/hour, while the Brazilian Midwest shows the highest wage/hour ratio. When comparing women living in the Midwest with those living in the Northeast, women working in the Northeast receive approximately $31 \%$ less than the workers in the Midwest. This result can be explained by factors associated with the regional development and agricultural modernization, as the Midwest region shows the intensity of capital use and high levels of modernization (CORREA; FIGUEIREDO, 2006). Given this evidence and based on the Theory of Segmentation it is possible to accept hypothesis 4 of this study.

The main contributions of this research refer to the detailing of the wage decomposition by genders in the agricultural sector of the Brazilian rural zone. In the detailing, it was observed that the gender wage differential decreases with the formality of the work, as well as with the increase of hours worked weekly by the women. The World Bank Group (2018) states that legal reforms that extend women's access to institutions can contribute to their rise to positions of authority as well as greater participation in the labor market. These results demonstrate the importance of policies and laws for encouraging and protect women to be part of the paid labor market.

Still on detailing od the wage decomposition, it should be noted that the female suffers from a remuneration punishment resulting from discrimination. Although women are more educated and have high work experience, their rates of payment are lower than those of men. In this respect, it should be noted that, even if the scenario found in this study remains the same, even if the women are engaged in the study, or start working early to obtain more experience, they will continue to earn a wage/hour lower than the men in the agricultural sector of the 
Brazilian rural zone. These results provide a better insight into the existence of gender discrimination in the rural labor market, adding contributions to the empirical studies on wage differentials in the Brazilian agricultural sector.

The results of this study have a theoretical contribution in people management, adding implications to wage policy issues for the agricultural sector. In addition, they contribute practically to wage issues, being informative to farmers and rural agricultural workers, providing results on the returns of investing in formal education, experience, as well as the importance of workload and formality in professional hiring. Social contributions related to the findings of discriminatory differentials and regional segmentation are also observed, requiring the design of public policies aimed to equalize social rights and combating discrimination. As a proposal for future research, it is suggested to conduct a longitudinal analysis to verify how these aspects have evolved over time, and with that, to identify if the gender wage differentials are decreasing or maintained over the years.

\section{REFERENCES}

AGRAWAL, T. Gender and caste-based wage discrimination in India: some recent evidence. J Labour Market Res. v. 47, p. 329-340, 2014.

AGUILAR, A. A. et al. Decomposition of gender differentials in agricultural productivity in Ethiopia. Agricultural Economics, v. 46, n. 3, p. 311-334, 2015.

ARROW, K. Higher education as a filter. Journal of Public Economics, v. 2, n. 3, p. 193-216, 1973.

ARULAMPALAM, W.; BOOTH, A.L.; BRYAN M.L. Is There A Glass Ceiling Over Europe? Exploring the gender pay gap across the wage distribution. Industrial \& Labor Relations Review, v. 60, n. 2, p. 163-186, 2007.

ASSIS, R. S.; ALVES, J. S. Hiato salarial entre homens e mulheres no Brasil segundo condição migratória: o mercado de trabalho é segregado ou discrimina? Revista Econômica do Nordeste, v. 45, n. 1, p. 120-135, 2014.

BECKER, G. S. Human capital: a theoretical and empirical analysis, with special reference to education. Chicago: The University of Chicago Press, 1964. 
BECKER, G. S. The economics of discrimination. Chicago: Univ. Chicago Press, 1957.

BERGOLO, M.; CARBAJAL, F. Exploring the urban-rural labor income gap in Uruguay: a quantile regression decomposition. Revista de Análisis Económico, v. 25, n. 2, p. 133-168, 2010 .

BIGLER, C.; AMACKER, M.; INGABIRE, C.; BIRACHI, E. Rwanda's gendered agricultural transformation: A mixed-method study on the rural labour market, wage gap and care penalty. Womens Studies International Forum, v. 64, p. 17-27, 2017.

BLINDER, A. S. Wage discrimination: reduced form and structural estimates. Journal of Human Resources, v. 8, n. 4, p. 436-455, 1973.

BRASIL. Lei n. 10.097, de 19 de dezembro de 2000. Altera dispositivos da Consolidação das Leis do Trabalho <http://www.planalto.gov.br/ccivil_03/Leis/L10097.htm>. Acesso em: 12 jul. 2018.

CARVALHO, A. P.; NERI, M. C.; SILVA, D. B. Diferenciais de Salários por Raça e Gênero: Aplicação dos procedimentos de Oaxaca e Heckman em Pesquisas Amostrais Complexas. Ensaios Econômicos da EPGE, v. 638, 2006.

CEPEA - Centro de Estudos Avançados em Economia Aplicada. Mercado de trabalho/Cepea: Remuneração no agro cresce mais que a da média brasileira. 2018. Disponível em: <https://www.cepea.esalq.usp.br/br/mercado de trabalho do agronegocio.aspx >. Acesso em: 11 jul. 2018.

CEPEA - Centro de Estudos Avançados em Economia Aplicada. PIB Agronegócio Brasil CEPEA-USP/CNA, jan./dez. 2017. Disponível em: <http://www.cepea.esalq.usp.br/pib/>. Acesso em: 11 jul. 2018.

CIRINO, J. F.; LIMA, J. E. Diferenças de rendimentos entre as regiões metropolitanas de Belo Horizonte e Salvador: uma discussão a partir da decomposição de Oaxaca-Blinder. Revista Econômica da Nordeste, v. 43, n. 2, p. 371-389, 2012.

COELHO, A. M.; CORSEUIL, C. H. Diferenciais salariais no Brasil: um breve panorama. Textos para Discussão, n. 898, p. IPEA, 2002.

CORREA, A. M. C. J.; FIGUEIREDO, N. M. S. Distribuição de Rendimentos na agricultura brasileira: uma análise exploratória com informações das PNAD's. Pensamento \& Realidade, v. 19, p. 5-38, 2006. 
CUNHA, M. S. Os empregados da agricultura brasileira: diferenciais e determinantes salariais. RESR, v. 46, n. 3, p. 597-621, 2008.

DOERINGER, P. B.; PIORE, M. J. Internal labor market and manpower analysis. Heath Lexington Books, 1971.

DOLTON, P.J.; MAKEPEACE, G.H. Sample selection and male-female earnings differentials in the graduate labour market. Oxf. Econ. Pap. v. 38, n. 2, p. 317-341, 1986.

EWING, B.T.; LEVERNIER, W. An analysis of Rural-Urban Differences in Average Family income: An Aplication of the Oaxaca and Cotton-Neumark Decomposition Techniques. The Review of Regional Studies, v. 30, n. 3, p. 299-314, 2000.

GARIBALDI, P. Personnel economics in imperfect labor markets. Oxford, England: Oxford Press, 2006.

GOLlin, D.; LAGAKOS, D.; WAUGH, M. E. The Agricultural Productivity Gap. The Quarterly Journal of Economics, Oxford University Press, v. 129, n. 2, p. 939-993, 2014.

GUIMARAES, C. R. F. F.; SILVA, G. Pay gap by gender in the tourism industry of Brazil. Tourism Management, v. 52, p. 440-450, 2016.

HAISKEN-DENEW, J.P.; MICHAELSEN, M.M. Migration Magnet: The role of work experience in rural-urban wage differentials in Mexico. Ruhr Economic Paper, n. 263, 2011.

HEADEY, D. D.; JAYNE, T. S. Adaptation to land constraints: Is Africa different? Food Policy, v. 48, p. 18-33, 2014.

HECKMAN, J. J. Sample selection bias as a specification error. Econometrica, v. 47, p. 153$161,1979$.

HLAVAC, M. Oaxaca: Blinder-Oaxaca Decomposition in R. R package version 0.1.4. Disponível em: <https://CRAN.R-project.org/package=oaxaca>. Acesso em: 10 jul. 2018.

HOFFMANN, R. Distribuição da renda e pobreza na agricultura paulista. São Paulo em Perspectiva, v. 7, n. 3, p. 107-115, 1993. 
HOLDEN, S. T.; OTSUKA, K. The roles of land tenure reforms and land markets in the context of population growth and land use intensification in Africa. Food Policy, v. 48, p. 88-97, 2014.

IBGE - Instituto Brasileiro de Geografia e Estatística. Estatísticas de Gênero Indicadores sociais das mulheres no Brasil. Estudos e Pesquisas, Informação Demográfica e Socioeconômica, Rio de Janeiro, n. 38, 2018.

IBGE - Instituto Brasileiro de Geografia e Estatística. Sistema de Contas Regionais: Brasil 2015. Contas Nacionais, n. 57, ISSN 1415-9813, 2017.

KASSOUF, A. L. Wage gender discrimination and segmentation in the Brazilian labor market. Economia Aplicada, v. 2, n. 2, p. 243-269, 1998.

MAHAJAN K., RAMASWAMI B. Caste, Female Labor Supply, and the Gender Wage Gap in India: Boserup Revisited. Economic Development and Cultural Change, v. 65, n. 2, p339378, 2017.

MINCER, J. Schooling, experience and earnings. Columbia University Press, 1974.

NEY, M. G.; HOFFMANN, R. Educação, concentração fundiária e desigualdade de rendimentos no meio rural brasileiro. Rev. Econ. Sociol. Rural, v. 47, n. 1, p. 147-181, 2009.

NOLTE, K.; OSTERMEIER, M. Labour Market Effects of Large-Scale Agricultural Investment: Conceptual Considerations and Estimated Employment Effects. World Development, v. 98, p. 430-446, 2017.

OAXACA, R. Male-female wage differentials in urban labor markets. International Economic Review, v. 14, n. 3, p. 693-709, 1973.

OECD - Organisation for Economic Co-operation and Development. Glossary of statistical terms, 2001. Disponível em: <http://stats.oecd.org/glossary/detail.asp?ID=1264>. Acesso em: 20 jul.. 2018.

PESSOA, D. G. C.; SILVA, P. L. N. Análise de dados amostrais complexos. In: $13^{\circ}$ SIMPÓSIO NACIONAL DE PROBABILIDADE E ESTATÍSTICA. Anais... São Paulo, Brasil, Associação Brasileira de Estatística, 1998.

PHELPS, E. S. The statistical theory of racism and sexism. The American Economic Review, v. 62, n. 4, p. 659-661, 1972. 
SCHULTZ, T. W. O valor econômico da educação. (P. Werneck, Trad.) Rio de Janeiro: Zahar, 1967.

SKINNER, C.J.; HOLT, D.; SMITH, T.M.F. Analysis of Complex Surveys. Chichester: John Wiley \& Sons, 1989.

TELLES, E. Who Gets Formal Sector Jobs? Determinants of Formal-Informal Participation in Brazilian Metropolitan Areas, Works and Occupations, v. 19, p. 108-27, 1992.

TRIVENTI, M. The Gender Wage Gap and Its Institutional Context: A Comparative Analysis of European Graduates. Work Employment and Society, v. 27, n. 4, p. 563-580, 2013.

UNDP. Human Development Report 2016, United Nations Development Programme, 2016.

VIETORISZ, T.; HARRISON, B. Labor market segmentation: positive feedback and divergent development. American Economic Review, v. 63, n. 2, p. 366-376, 1973.

WORLD BANK. World development indicators: Rural environment and land use: Environment, 2016. Disponível em: 〈http://wdi.worldbank.org/table/3.1\#>. Acesso em: 13 dez. 2018.

WORLD BANK GROUP. Women, Business and the Law 2018. Washington, D.C.: Grupo Banco Mundial. Licença: Creative Commons Attribution CC BY 3.0 IGO, 2018. 